\title{
Tumbling Down
}

\section{Mark Smith}

For Simon, A certain amount of healing had taken place by the time Tess got in touch. He had started work again, reconnected with friends and discovered the beautiful mindlessness of swimming laps at his local pool two mornings a week.

It had been four years since he had seen Tess. The first six months were the hardest. It was like living in London in winter, with every day dissolving from murky grey into premature darkness. He groped his way forward, catching glimpses of her everywhere - the smile of a girl on the tram, the eyes of a certain actress, the nape of a woman's neck at the supermarket checkout.

Then, in the nineteenth month, came a tentative, one line email:

The Ship Song, a skylight above the bed, the river bend.

Simon stared at the words, each little phrase so succinct, each attached to a lucid memory, a sound, an action, a volume inside his chest. They saw Nick Cave at The Espy on a bitterly cold Melbourne night. Inside it was warm and humid with little droplets of moisture falling intermittently from the low ceiling. The Ship Song had the crowd swaying, pushing against each other. He'd only just met Tess but as the chorus swelled she threaded her fingers through his and drew her mouth close to his ear. To this day he doesn't know what she said but the warmth of her breath and the way she pushed her breasts against him said as much as he needed to hear.

The rest of that winter and spring were a haze for Simon. His other friendships fell away slowly, his studies were put on hold and he organised casual jobs around Tess' uni timetable. He would meet her in the afternoon and they'd go back to her place for sex. He'd wake in the early evening to find her propped up on her pillow with a textbook in her lap and a highlighter pen between her teeth. He learned to give her space, tiptoeing to the kitchen and making her toast and honey. 
He'd slide back into bed with two cups of tea and feed her the toast, cupping his hand under her chin to stop the honey dropping onto the bed. She'd pretend to ignore him and pull the sheet up across her breasts, smiling.

Simon placed himself somewhere around the middle on the scale of male attractiveness, not strikingly handsome in a Brad Pitt kind of way but not weird in a Steve Buscemi way either. But Tess, gorgeous darkhaired, green-eyed Tess, saw through every shambolic gesture, every reason he put to himself to justify her not being interested in him. She stripped everything away from him and still liked what she saw.

They stayed at an old farmhouse near Daylesford that long and golden summer. Their bedroom had a skylight above the bed. In his anger at her leaving he had swept her from every corner of his memory but there was one image that he couldn't expunge. He woke one morning to find her standing naked on the bed. Minute specks of dust filled the air inside a shaft of light, shifting and moulding themselves around her body. She moved her arms slowly through the air, the tiny particles giving way before being drawn back to her skin by static. She turned, looked back down at him and smiled, a halo encasing her body, clothing her in light. 'Look,' she said and what he saw was the smooth curve of her buttocks, the dark hair cascading down her back and the swell of her breast.

One evening they walked across the home paddock to a bend in the river. Tess walked ahead of him, disturbing the flurries of insects and grasshoppers, their gossamer wings catching the light. One piece at a time she removed her clothes and dropped them in the grass. 'We have to mark our trail,' she laughed. He saw the arch of her back as she lifted the T-shirt over her head. At the far fence she slipped through the railing and discarded her shorts, easing them down her legs and, as she wound down through the undergrowth to the riverbank, she hooked her thumbs into her pants and stepped out of them before running the last few metres and launching herself into the water.

It's hard to say how things unravel. As a smoky Melbourne autumn descended into the grey winter, Tess dedicated herself to finishing her 
degree while Simon drifted from one short-term position to another. They spent their weekends in each other's beds trying to recapture the glow of summer at the farmhouse, but all they found under the dim wash of the bed lamp was a cold that ate into their bones. They argued about trivial things because they were too afraid argue about the things that really mattered.

Finally, with an abruptness that shocked him, she left the warmth of his side and pleaded with him not to follow. She needed space she said and she took it, moving to Perth, placing a desert between them.

Simon replied tentatively to the email and they began to correspond. She had married Michael, a kind and gentle man, she said. He worked in the mines, fly in fly out. They had a child, Hannah. She loved her husband but found the weeks alone without him difficult. The emails were full of assumptions about what he would know and understand, unspoken details anchored in their history, but while he searched for signs of intimacy, he found none.

In the fourth year she wrote to say, we're coming to Melbourne; would love to catch up.

And then there she was, stepping through an elevator door, stopping and leaning forward, smiling and looking down in that nervous way she sometimes had. When she was younger this brought her hair forward over her face, veiled and protected her. Now her hair was cut short but the charm of the little movement lingered.

She walked across the foyer and they kissed awkwardly. There was no pushing of one against the other to close out the space that had grown between them.

She was always good at disarming him - startling him with an intimacy he wasn't expecting. 'You smell nice,' she said. It was a means, he knew, of connecting, relieving the need for pleasantries, cutting through.

'Would you like to come up and meet Michael and Hannah?'

Simon wasn't sure of the arrangements for this meeting, what the expectations were.

'Sure,' he replied. 
In the elevator he had the chance to look at her more closely. With only the one golden image in his head he had been trying for weeks to reconstruct her in his mind, the lushness of her body, her smile, her slow and gracious movements in that shaft of light. Now she seemed smaller, her features more defined. There was a boyishness about her body that he had never seen.

There followed a blur of introductions - an old friend, she called him - and wary conversation, she in her comfort as mother and wife, he searching for pleasantries, all the while trying not to stare at her. She held her child with effortless grace, protruding one hip slightly and resting the baby on it. He noted the comfortable, unspoken understandings between husband and wife.

In that instant he felt like an island set adrift from the mainland in some primordial upheaval - everything he knew and understood had been shifted, connections of root and soil dragged and separated. He was no longer part of her. Her history had diverged from his and more than anything, he wanted to rewrite it, to go back to the night in Fitzroy when she left him, to hold her there, to beg, to stop her from following her instinct to run. He reworded the desperate conversation as she hailed a cab on Brunswick Street.

'Please Tess. Stay. Don't do this. I'm sorry.'

Anything. Any word that would force her to look at him, any action that would stop her from getting into the taxi and screaming at the driver. Anything that would compel her to turn and look back at him standing in the rain, the glistening tram tracks beside him, the cars halted behind, blaring their horns at the madman, his hands on his head, blocking their way.

Michael took the baby from Tess and said, 'Why don't you two go for a drink; you must have a lot of catching up to do. I'll put Hannah down.'

Michael extended his hand as they left. 'Nice to meet you.' Simon felt the strong grip of a man with total confidence in the rightness of his world. There was no tilting of the surface that held his feet, no unexpected chasms to fall into. 
The conversation as Simon drove was unadventurous. He asked how she had met Michael, where she was working, how she found living in Perth. She nervously effused about the sunshine, the cost of childcare and swimming at Cottesloe.

They settled on a bar in a laneway off Rathdowne Street where each glass of wine dissolved more of their awkwardness. He noted the way she didn't speak about anything in the singular. Her life had become we and us.

'We plan to spend a year doing volunteer work on a remote community in the Kimberley.'

'Hannah has brought us so much pleasure.'

She spoke brightly and relentlessly of a plural future.

She coaxed and cajoled him while he fought to remind himself of the way she would steal the oxygen from the air when she left, suck it from his lungs, leaving him short of breath. He reminded himself of the brief elation before the fall, of the days that would follow when he would fight the need to call her, just to hear her voice. He reminded himself that this was no longer even an option.

Later, when he tried to piece the conversation together, he could only recall fragments. He couldn't be sure of the actual words because they had been broken up and reshaped by his lucid awareness of her leaning across the table, the straps slipping from her shoulders, the colour of fading sunburn at the nape of her neck.

He remembered moments - her hand resting on his arm, their legs touching under the table, the easy smile that lit her face, the swiftness of the movement that took them back to the car, the awkwardness of his opening and closing doors, his sudden clumsiness with the world he occupied so confidently in her absence.

He drove slowly and carefully back to the hotel, where they sat in the car, a thick silence between them as they feigned interest in the passers by.

'So,' he finally said, 'what was this all about?'

She turned to him, paused and replied, 'I can't pretend anymore that you don't exist. I don't mean to make things hard for you - I see the 
way you still look at me. You're still my reference point for so many things Simon. And,' she paused, 'I don't want you to remember me for what happened that night in Fitzroy. I'm sorry for the way it ended.'

'It's okay. I didn't know what I had,' he replied.

'I have to go,' she said.

He was never good with the ritual of goodbyes. There was a way it could be done cleanly and neatly but he never quite got it. He rummaged through his memory for words that would slow the moment, that would warp the arc of time and make her see him as she must have when she looked back down in that pool of light on the bed.

She leaned over, kissed him briefly on the lips and stepped out of the car. 